\title{
Wetenskapsteoretiese besinning oor die grondslae van die Diakoniologie
}

\author{
B. Spoelstra \\ Departement Diakoniologie \& Missiologie \\ Potchefstroomse Universiteit vir $\mathrm{CHO}$ \\ POTCHEFSTROOM
}

\section{Theoretical perspective on the foundation of Diaconiology}

In this article it is argued that theology must be practical to have meaning. The author of this article attempts to determine whether 'practical theology' and 'diaconiology' are the same discipline or whether they are different disciplines within the science of theology. It is alleged that diaconiology differs intrinsically from practical theology when the point of departure, prepositions and theological positions are taken into account. Practical theology is based on the empirical church and its actions. Diaconiology should take as its point of departure the kingship (kingdom) of God in this world. It is conceded that the reformed diaconiological tradition got stuck in formal ministries. The article propagates the development of diaconiology, inter alia by means of a critical investigation of the process by which God encounters man and church. It is concluded that an empirical analysis of the official ministries may be necessary to establish whether the kingdom of God is indeed actualized in practice.

\section{Inleiding}

Oor diakoniologie as sodanig word - in teenstelling met praktiese teologie - tans baie min gepubliseer. Die VU van Amsterdam waar die term diakoniologie ontstaan het, praat nou van praktiese teologie. Is Praktiese Teologie en Diakoniologie net twee name vir dieselfde vak (Spoelstra, 1991:214, Louw, 1992:125) of het ons hier met twee verskillende wetenskaplike benaderinge, miskien selfs verskillende 'teologieë' te doen?

Volgens Venter (1992) lê die verskil in 'rasionaliteit' tussen diakoniologie en praktiese teologie daarin dat diakoniologie in relasie tot die Woord van God die "bediening in die kerk" ondersoek, terwyl 'praktiese teologie' kerklike of kommunikatiewe handelinge 'in diens van die evangelie' in re- 
lasie tot die empiriese kerk bestudeer. Hierdie koppeling aan óf die Woord van God óf aan die empiriese kerk dui op twee verskillende studievelde en daarom twee verskillende wetenskappe.

Pieterse (1994:99) meen dat 'n "kommunikatiewe handelingsteoretiese benadering in diens van die evangelie" vir Praktiese Teologie meer bied "as die konfessionele of diakoniologiese benadering", sonder dat hy die konfessionele of diakoniologiese benadering (behalwe vir enkele verwysings na 'n verouderde Kuyper) geanaliseer het. Die "eie metode en staanplek in die ry van wetenskappe" sowel as die ontwerp van eie "teologiese teorieë" wat praktyk-georiënteerd is, sou aan praktiese teologie groter ruimte as aan diakoniologie gee. Verder is vroeër al gewys op die neiging om praktiese teologie as 'n 'alternatiewe teologie' te ontwerp en die gevaar dat die vak sodoende kan opgaan in 'n antropologiese "godsdienswetenskap" wat teenoor die ander teologiese dissiplines te staan kom (Spoelstra, 1992a: 316; vgl. Kuyper, 1909a:173).

Tog is die onderskeid tussen diakoniologie en 'praktiese teologie' nie duidelik nie, selfs nie wanneer Venter (1992:30-34) sê: "Die diens van die kerk is die besondere gerigtheid in die diakoniologiese denke" (vgl. vir dieselfde Dijk, 1952:16, 30 en Jonker, 1968:24). Wie en wat is die 'kerk' wat diens lewer? - staan die studie dan nie ook maar in verband met die empiriese kerk nie? Aan Pieterse sou mens kon vra wie of wat is 'die evangelie' wat diens vereis? 'n Mens sou ook kon verwag dat Dijk se beroep op Calvyn (1952:15) die werk ('kommunikatiewe handelinge'?) van Christus en nie die kerk nie as "die besondere gerigtheid in die diakoniologiese denke" sou uitwys.

Die begrip bediening in die kerk mag soos by Kuyper (1909b:468-483) diens van 'ampte' in 'n organisasie of onder gelowiges aandui, terwyl 'diens van die kerk' in Roomse sowel as in verenigingsregtelike sin diens is wat die klerus of organisasie verrig. Wanneer iemand kerk en gemeente vereenselwig (Spoelstra, 1989:2-8) op grond van die Konfessie (Heid. Kat. 21, NGB 27-30) en eksegese onderskei van ekklesia in die Nuwe Testament (vgl. Snyman, 1977:24-27, 35 e.v; Du Plooy, 1982:64-120), kan 'diens van die kerk' die aktiwiteite van gelowiges, die sogenaamde 'amp van gelowige(s)' omvat. Vae terminologie, verwarrende en selfs botsende begrippe soos kerk, amp, diens en die relasie tot God bemoeilik 'n analise van diakoniologie en praktiese teologie. 
Rome (en ons gangbare spraakgebruik) vereenselwig kerk met amp. Luther se twee-ryke-leer maak sigbare (empiriese) preekkerk los van die onsigbare kerk (liggaam van Christus). Die verenigingsreg het van 'kerk' 'n objektiewe fenomeen, 'n "Dienstleistungsbetrieb für Religion" (Bohren, 1975:184) gemaak, terwyl die gereformeerde konfessie 'kerk' identifiseer met gelowiges, uitverkorenes. Die konnotasie waarin begrippe soos kerk, diens, amp, handeling, kommunikatiewe handeling, ensovoorts, gebruik word, behoort met die oog op wetenskaplike debat duideliker aangedui te word. Teoloë behoort hulle prolegomena soos in die aanhef van 'n wet eers op die tafel te plaas om te verhoed dat wat bedoel word, verskil van wat verstaan word. Die mate waarin begrippe verskil, sal die verskil tussen diakoniologie en praktiese teologie uitwys.

Daar is ' $n$ bepaalde kerkgerigtheid in kontemporêre teologie anwesig (Bohren, 1975:20-23, 175-190; Spoelstra, 1992a:308 e.v.). Schleiermacher het die sigbare fenomene kerkinrigting en godsdiens aan die begrip praktiese teologie verbind (Schleiermacher, 1830:24 e.v.).

Hierdie artikel aanvaar die hipotese dat gangbare 'praktiese teologie' die praktyk of handelinge van, deur en in die 'empiriese' kerk op die oog het, terwyl 'diakoniologie' die handelinge van God (heerskappy, koms van sy koninkryk) met, deur en in mense in die lig van die Bybel wil bestudeer. Ook word aanvaar dat die wetenskaplike grondslae in 'n duidelike verskil in wetenskaplike opset tussen praktiese teologie en diakoniologie behoort te manifesteer.

Die handelinge van God wat vandag plaasvind, is nie in die Bybel opgeteken nie. Die Bybel is egter gegee om die handelinge van vandag, of liewer van die God agter die handelinge te ken (NGB 2). Die handelinge geskied direk deur Woord en Gees, maar ook middellik deur dienaars (nie altyd ampte nie) wat God gebruik. Ook hier is twee opvattings moontlik: God roep en gebruik 'n dienaar selfs voor daar 'n kerk kan wees (Rom. 10:14) - of ' $n$ verenigingsregtelike idee dat God sy werk na dienaars of die kerk delegeer. Soms bly net die gelowiges voorwerpe van diens (Kuyper, 1909b:468-481; Dijk, 1952:12, 226 e.v.); soms word hulle ook subjek van diens. Enkele kontoere word getrek om diakoniologie ietwat te omlyn.

\section{Verskillende aksente op teologie as wetenskap}

Teologie het vir Augustinus volgens die Griekse model wysheid beteken (Jonker, 1977:3-7). Die teologie van die Reformatore was deur en deur 
prakties met die oog op die belydenis en lewe van gelowiges in teenstelling met ongeloof en dwaling. Teologie behoort nie teorie te wees nie, maar prakties (Haendler, 1957:5; vgl. Pannenberg, 1976:231-240, 347, 350358, 433 e.v.; Jonker, 1968:5 e.v., 15). Abstrakte filosofiese en ontologiese teologie se dae is getel (Smalbrugge, 1991:92).

Schleiermacher se 'praktiese teologie' is anders 'prakties' as dié van die Reformatore. Schleiermacher het aangesluit by Kant wat teorie en praktyk geskei het en in sy rasionalistiese benadering ontken het dat teologie as wetenskap beskou kan word omdat God nie as objek vir positiewe ondersoek beskikbaar is nie. Volgens Schleiermacher kon teologie egter die geloof of godsdiens van mense empiries ondersoek. Die rasionalistiese en positiwistiese idee word vandag skerp bestry (vgl. Pannenberg, 1976:433; Schleiermacher, 1968:20; Spoelstra, 1992a:304, 1993:76 e.v.; Kuyper, 1908:48-56; Bohren, 1975:183 e.v.). Die idee dat 'praktiese teologie' sonder dogma (geloofsaanname) beoefen kan word, is onmoontlik (Fischer-Barnicol, 1969:93).

Bohren (1975:20) sê omtrent dieselfde:

Der Theologie studiert hierzulande eine Theologie, die als evangelische Theologie vom Humanismus herkommt und durch die Aufklärung mitbestimmt is ... Man liebt es, sich über Studienreform zu unterhalten. Solche Unterhaltung ist möglicherweise das beste Mittel wenig oder nichts zu veränderen!

Die Aufklärung het 'n disfunksie tussen teorie en praktyk veroorsaak sodat teologie wat in "steriler Reinheit" beoefen word, "eine Praxis (ist) ohne die Praxis des kirchlichen Alltags" (Bohren, 1975:21,23). Volgens dié uitgangspunt moet die teologie omtrent die universele kerk in die praktyk van die (empiriese) kerk grondvat.

Kuyper (1909a:186) stel dat teologie die volgende impliseer: "De ons geopenbaarde kennisse omtrent het mysterie van het Drievoudig Wezen Gods...". Teologie sê ons iets omtrent God. Tog dek sy definisie nie wat hy in sy Encyclopaedie $(1908,1909)$ as teologie aanbied nie. Hy erken die skepping as openbaring, maar noem net die Heilige Skrif fons of principium theologiae (Kuyper, 1909a:222; vgl. 214 e.v., 247, 295, 301). Teologie word met "onderzoek van deze Heilige Schriftuur" vereenselwig (Kuyper, 1909b:6; vgl. Spoelstra, 1993:78-84). Indien teologie net die Skrif as bron bestudeer, gaan teologie in bibliologie of diakoniologie in biblisisme op. 
Tereg sê Pieterse (1994:95) dat jou opvatting oor teologie jou aanpak bepaal en vir hom is teologie (in ooreenstemming met Schleiermacher) tot op groot hoogte die "wetenskaplike bestudering van mense se geloof in God" - omdat "bestudering van God" onmoontlik is. Wie egter voorveronderstel dat God hom openbaar het (NGB 2), ag teologie oor God moontlik.

Semmler het teen die einde van die 18de eeu twee onversoenbare strome in die teologie uitgewys. Hornig (1991:727) sê in hierdie verband:

Die Position einer gesetzlichen und fundamentalistischen Bibelautorität die ausnahmlos alle biblischen Angaben und Vorstellungen als verbindlich ansieht, und die Position eines modernistischen Relativismus, der das Zeitbedingte akzentuiert und es kaum noch gestattet, von einem bleibend gültigen 'Worte Gottes' in der Bibel zu reden.

Die vraag is egter of fundamentalisme en relatiwisme die enigste moontlikhede bied. 'Diakoniologie' wat kennis van God en die koms van sy koninkryk (teologie) in die 'geloof' en ervaring van mense met die Bybel as norm bestudeer, sal van 'praktiese teologie' verskil wat die godsdiens en ervaring van mense in ' $n$ bepaalde era as ondersoekveld neem en as gegewe fenomeen met behulp van moderne menswetenskappe analiseer.

Teologie moet die mens met wie en deur wie God handel en die tyd waarin dit gebeur, ken. Daarvoor is hulp van ander wetenskappe nodig. Opleiding behoort ' $n$ predikant te ontsluit vir omgang met mense, met sy eie tyd en met God self. Dié aspek word dikwels in die opleiding verwaarloos deur die oorbeklemtoning van die ou tale (vgl. Marti by Bohren, 1975:19 e.v., 170). Die vermoë om krities (onderskeidend) na die totale mens in 'n bepaalde tydsgewrig te kyk is noodsaaklik (vgl. Ef. 6:12). Hierdie kennis is egter nie teologie omdat dit vir bediening noodsaaklik is nie.

Elke teologiese dissipline moet die veld of verskynsel waaroor kennis ingewin word, skerp omlyn. Tegelykertyd moet hy hom rekenskap gee van die metode(s) waarmee kennis ingesamel en geverifieer word. So sal byvoorbeeld die omlyning van die veld van ondersoek van elke dissipline en die metode(s) wat in die ondersoek gebruik word, bepaal of ons byvoorbeeld met sosiologie of teologie besig is (vgl. Stoker, 1969:134-138, 241 e.v.; Spoelstra, 1993: 74-76). Hierdie omlyning en metodes kan nie sonder bepaalde voorveronderstellings gedoen word nie. 


\section{Noodsaaklike voorveronderstellings}

Die rasionalisme wou niks van 'geloofsaannames' (apriori) in teologiese wetenskap weet nie. Tans word die noodsaaklikheid van basiese aannames of veronderstellings by die beoefening van wetenskap erken (Venter, 1992: $34,41,44)$. In die lig hiervan kan die gereformeerde diakonioloog sy voorveronderstellings ten opsigte van God, Bybel, konfessie en gevolglik sy begrip van kerk, diens ensovoorts, op die tafel lê. Hy gaan sodoende meer wetenskaplik te werk as 'n teoloog wat voorgee dat hy sonder dogma, teorieë of geloofsaannames bloot 'prakties' te werk gaan.

Wanneer Pieterse (1991b) met Van Wyk (1991) gesprek voer, gee hy hom van sy voorveronderstellings rekenskap (vgl. Pieterse, 199la:44) en vermoed hy dat Van Wyk ander voorveronderstellings het (Pieterse, 199lb: 253). Voorveronderstellings raak sake soos geloof dat God is of nie is nie, dat Hy hom in die Skrif openbaar of nie openbaar nie. Oor voorveronderstellings kan geredeneer word - terwyl rasionaliste neig om Skrifgeloof as fundamentalisties af te skryf. Ondertusseen val dit op dat teoretiese besinning oor praktiese teologie nog aan die gang is en steeds 'eerste treë' gewaag word om praktiese teologie te beskryf (Heyns \& Pieterse, 1990, vgl. Dreyer, 1991). Is sosiologies-antropologiese apriorieë en empiries-kerklike gerigtheid sonder om voorveronderstellings te verantwoord daarvoor verantwoordelik? Waar vind ons in 'praktiese teologie' 'n duidelike teologiese (op God gerigte) en daarom Christologiese en Christokratiese perspektief?

Diakoniologie en 'praktiese' teologie gaan myns insiens uiteen wanneer 'n Christologiese vertrekpunt teenoor 'n ekklesiologiese vertrekpunt gestel word (vgl. Dijk, 1952:14-20, 26-30). Kerkbegrip en gesagbegrip is basiese voorveronderstellings wat weer ander begrippe soos bediening, handeling of praktyk bepaal. Elders (Spoelstra, 1992b) het ek kerklike gesag probeer ontleed en aangedui dat Rome en Calvyn albei 'n Christologiese basis vir kerklike bediening aanvaar het. Ons het in Suid-Afrika egter uit Nederland en 17de-eeuse verenigingsreg (vgl. De Wet, 1921; Kuyper, 1883:51) 'n oorwegend ekklesiologiese diens- en gesagsbegrip geërf. Klooster (1977:21) wys dat baie mense enigiets wat met 'kerk' te doen het as 'teologie' aanvaar. 


\section{Die dilemma ten opsigte van die veld van ondersoek}

Pannenberg (1976:363) wys daarop dat die proses waardeur ondersteunende teologiese dissiplines selfstandigheid verwerf, ' $n$ veld is wat nog onontdek is. Nel (1987:26) wys daarop dat praktiese teologie moeite het om sy deeldissiplines te definieer (vgl. ook Spoelstra, 1991:206). Pieterse (1991b:249) sowel as Van Wyk (1991:83) vind dit onmoontlik om te sê wat 'teologie' is. Wat wil die begrip 'praktiese' teologie dan sê? Indien 'teologie' net mense se geloof, geloofuitsprake, ervaring of handelinge oor godsdiens moet ondersoek, begryp ek volkome Bohren (1975) se roep om 'n trinitariese en pneumatalogiese 'praktiese teologie' wat (weer?) moet verseker dass Gott schön werde (vgl. Dingemans, 1987:11 e.v., 130-135, 212-216).

Gereformeerde 'diakoniologie' (Kuyper, 1909 b:468-483, vgl. Dijk, Jonker, Venter, Te Velde) moet op voetspoor van Calvyn (1992:1265, 1317 e.v.) let op die wyse waarop God wat hom in sy Woord geopenbaar het met Woord en Gees in mense en deur middel van mense handel. Diakoniologie moet nie net sê wat mense doen nie (praktiese teologie), maar moet aantoon hoe God daarin handel. Kuyper en die Neo-Calviniste kon hulle nie heeltemal vrymaak van die ekklessiologiese en klerikalistiese visie van hulle tyd nie (vgl. Spoelstra, 1991, 1992a, 1993) en 'diakoniologie' het by hulle (vgl. Kuyper, Dijk e.a.) in baie opsigte bly steek by die 'ampte' en nie uitgekom by die diakonia waarin die kerk, gelowiges en ampte solidêr optree nie.

Bohren $(1975: 44,117)$ het die verabsolutering van die kerk in die huidige 'praktiese teologie' skerp afgewys en teoloë beskuldig dat hulle die groot dade van God onder ons verhinder omdat hulle God nie meer vertrou nie en sonder profetiese sin hulle met die Banalen verbind het. Bohren (1975: $86,166-174,200,212$ ) wys op die oordrywing van vakspesialiste binne vaktronke wat probeer om weer van hulle intelligenste studente 'vakidiote' te maak binne 'n kerksisteem waar Kirchenfürsten heers. Hy (Bohren, 1975:184) sê:

Kirche wird hier unter dem Vorzeichen der Leistung gesehen, als Dienstleistungsbetrieb für Religion. Das Handeln Gottes aber scheint kein Problem mehr zu sein. Es wird verdrangt durch die Funktion Religion. Die Frage ob Gott Gott sei im kirchlichen Handeln, wird gar nicht erst gestellt.

Die vraag na wat God self met, deur en in mense doen, behoort in diakoniologie voorop te staan. 
Teenoor die verabsoluteerde ekklessiologie bepleit Bohren (1975:233) 'n teosentriese praktiese teologie wat primêr in relasie tot God staan:

Wenn Theologen ihre Einheit in gemeinsamer Klage und gemeinsamem Lobe suchen, wird auch die schuldhafte Kirchenspaltung zwischen Klerus und Laien aufgehoben und die Kirche schön. Das ist eine Weissagung auf die Verheissung des Geistes hin ... Wenn Gott erkannt wird als Gott, wenn er im Geist auch sich heraustritt in unserer Horizont, wird es zum Schrei des Entzückens kommen über seine Schönheit. Kirche und Theologie sind dann nicht langer auf der Suche nach einer verloreren Zeit, sondem da, präsent in der gegenwart des Geistes in dem sie ihre Einheit haben und schön werden.

\section{Praktiese teologie neem die kerk as vertrekpunt}

Haendler (1957:5) sê met verwysing na Schleiermacher dat praktiese teologie die volgende wil wees:

Wissenschaft von der (gegenwärtigen) Kirche. Und wie er den Dienst des Pfarrers als Dienst der Kirche verstehen lehrt, so fügt er den weiteren grössen Gesichtspunkt hinzu, den er als Kirchenregiment bezeichnet. Das ist ... alles Tun, das, durchaus ebenso innerlich-geistlich wie ausserlich, die Kirche und ihr Leben leitet. Die gesamte Theologie ist leitende Kraft in der Kirche. Und Kirchenleitung ist im weitesten Sinne zu nehmen, ohne dass an eine bestimmte Form zu denken ware."

'Praktiese teologie' het "altyd te doen met die lewe, wese en werk van die kerk" (Johanson, 1973:176). Wanneer praktiese teologie van die empiriese of sigbare kerk uitgaan, moet dit óf die kerk as liggaam van Christus buite rekening laat, of die empiriese kerk vaag teen die agtergrond van die universele kerk laat sweef, óf onkrities die empiriese kerk daarmee identifiseer. Waar praktiese teologie meesal op die empiriese fenomeen toespits, neig dit altyd weer om in kerksosiologie of kerkpsigologie op te gaan omdat die mistieke band met die eintlike kerk, die universele, gemis word (Spoelstra, 1992a:315). Hierdie band wil die Belgiese Konfessie in artikel 29 na vore bring: die universele kerk kan voorwaardelik in die empiriese kerk sigbaar word en daarmee identifiseer.

Heyns en Pieterse (1990:7) sê dat 'praktiese teologie' 'n perspektief op teologie as geheel het - 'n stelling wat moeilik is om te verstaan. Volgens Heyns en Pieterse sou praktiese teologie "geloofshandelinge van mense" bestudeer wat as "kommunikatiewe handelinge in diens van die evangelie" kwalifiseer. Wanneer hulle dit verduidelik, kom dit tog maar neer op die bestudering van kerklike handelinge. Die kwalifikasie "in diens van die evangelie" verander nie wesenlik die stelling nie (vgl. kerkgerigte argumentasie by Heyns \& Pieterse, 1990:6-12; Firet, 1968b:6 e.v. met verwysings; 
Jenssen, e.a. 1975, vgl. subtitel; Haendler 1957:1, 15). Firet $(1968 b: 8,9)$ plaas 'n waardevolle aksent op die "intermediërend menselijk handelen" waarby God, mens en wêreld betrokke is, maar betrek praktiese teologie in die kader van "de verkondiging en van de kerk", waarin kerk "intermediair" is en praktiese teologie "het feitelijke funktioneren van de kerk" ondersoek.

Die vraag wat onder kerk verstaan word, is derhalwe van wesensbelang om 'praktiese teologie' te tipeer. Met die Lutherse skeiding van sigbare (empiriese) en onsigbare (ware) kerk kan die kerk bloot empiries as sosiologiese verskynsel verstaan word. Wanneer Hendriks (1990) skryf oor die wyse waarop 'n "vitale en aantrekkelijke gemeente" opgebou moet word, betrek hy die sosiale wetenskappe daarby. Pieterse (1991a:38) doen in verband met die "wetenskaplike rasionaliteit" van praktiese teologie dieselfde. 'n Mens kan moeilik 'n ander afleiding maak as dat die perspektief van 'praktiese teologie' op die kerk as sosiale gemeenskap kerksentries en nie Christosentries gerig is nie.

\section{Praktiese teologie as handelingswetenskap}

In aansluiting by Gadamer en Habermas wat gesprek tussen wetenskappe beklemtoon, het Zerfass in 1974 met 'n artikel oor praktiese teologie as handelingswetenskap (Pieterse, 199 la:43 e.v., 199lb, 1994:93; Booysen, 1980:6) gelei na 'n nuwe definisie van praktiese teologie wat gerig sou wees op "alle handelinge wat in diens van die kommunikasie van die Evangelie staan" (Nel, 1991:24, 29; Pieterse, 1994:94) en daarom ook met die menswetenskappe in gesprek tree.

Louw (1993:206 e.v.) vra wat van die teologiese en wetenskaplike gehalte van die 'vak' met hierdie definisie word en of enigiets wat met kerklike bediening in verband staan teologie is (vgl. Bohren, 1975:164-223). Hy vra wat met handelinge en empirie bedoel word en wys hoe noodsaaklik 'n norm vir praktiese teologie is - anders verval dit in 'n "fenomenologie van geloofsgedrag". Pieterse (1991a:44) wys daarop dat God, die Skrif en die Gees uitgeskakel word wanneer menslike handelinge die vak bepaal.

In hierdie verband stel Bohren (1975:212 vgl. 200) ook die volgende:

Dass die Praktische Theologie die Humanwissenschaften braucht, steht ausser Zweifel ... Die Frage ist, ob Theologie, die sich mit diesen Wissenschaften ins Gespräch begibt, kritisch genug ist, die Geister der Wissenschaften zu prüfen ... Ohne identitat ist er nicht gesprächsfahig. 
Die identiteit kan slegs uit 'n gesprek "mit der Väteren" oor eie herkoms bekom word. Hierdie voorwaarde geld in besonder vir diakoniologie.

Louw (1992:122) gee aan praktiese teologie die taak om "ontmoetingsgestaltes van die heil" te ondersoek. Maar waarom tree die gestalte (personifikasie?) van objektiewe heil so sterk na vore dat sy heil eerder as die Gewer van heil beklemtoon word? Is heil nie te eng soteriologies geformuleer, terwyl God veel meer met, deur en in mense doen nie? Waarom kan dié heerskappy van God in en deur mense (koninkryk) nie as vertrekpunt geneem word nie? Louw vra tereg of die blote handelinge (fenomenologie?) wat bestudeer word teologie kan wees. Kan 'handelinge in diens van die evangelie' ondersoek word sonder die wat en waarom (geloof en dogma) wat die handeling wil dien? Praktiese 'teologie' wat op 'handelinge' alleen toespits, kan in die studie van die toepassingstegniek van resultate van ander dissiplines verval. Kerkreg en kerkgeskiedenis bestudeer immers ook 'handelinge in diens van die evangelie'.

\section{Diakoniologie vertrek vanuit die 'bediening' van Christus}

Venter (1992:49) onderskei 'diakoniologie' van 'praktiese teologie' as "teologiese wetenskap wat op rasionele wyse vanuit die werklikheid van die Bybel as norm die bediening van versoening in sy verskillende gestaltes in kerk, kosmos, en koninkryk ondersoek. Hierin is die empiriese werklikheid rigtingwyser ....". 'Bediening' bring die waardevolle eenheid tussen die wat, waarom en hoe van die handeling na vore. Daar is iets wat bedien word.

Die definisie van Venter roep egter ook vrae op: Waarom word 'bediening van versoening' en nie 'bediening van die koninkryk' as veld van ondersoek geneem? Waarom word 'koninkryk' naas kosmos en kerk as 'n sfeer vir die bediening gestel, terwyl koninkryk die heerskappy van God is (Ridderbos, 1950:36, 41; Heid. Kat. 48) waarbinne versoening plaasvind? Christus het tog gekom om die koninkryk deur versoening te vestig (Mark. $1: 14$, Luk. 4:43). Is die kerk nie ook vrug van die koninkryk nie (Heid. Kat. 48)? Wat hou die voltooiing van die koninkryk vir die kosmos in (1 Kor. 15:24)? Wat word bedoel met 'empiriese werklikheid' as "rigtingwyser'?

Diakoniologie het bestaansreg wanneer sy apriorie rus in Christus (die Here en sy koninkryk). God, die Here kom na die wêreld om te regeer 
(vgl. Firet by Nel, 1991:32). Bediening deur die diens van mense (amp) vergestalt reeds in die vroeë kerke die koninkryk waar Woord en Gees regeer (Spoelstra, 1992b; vgl. Calvyn, 1992:1308, 1319; Spoelstra, 1981: 11-16). Ridderbos (1950) en Van Ruler (1952:16-24, 36 e.v., 50 e.v.; Dijk, 1952:8) het na die Tweede Wêreldoorlog die teokratiese visie op die gemeente beklemtoon. Van Ruler wou die koninkryk in die lewe van Christene indra. So ' $n$ benadering is Christologies gefundeer.

'Koninkryk' sê baie meer as 'Bybel' omdat God Hom nie net in die Bybel openbaar nie (NGB 2). 'Diakoniologie' moet die koms (bediening en vergestalting) van die koninkryk van God ondersoek in soverre dit aanwesig, maar ook toekomstig en wyer as die kerk is (vgl. Ridderbos, 1950:51-68, 102-104, 296-308). Wanneer die koms van die koninkryk nie die essensie van die diakonia van ampte en Christene is nie, het Bohren (1975:21-23) gelyk dat kerklike bediening mense sterk in wat hulle wil glo. So dien die kerklike bediening nie "Neuschöpfung, sondern der Bestätigung des Bestehenden. Die Nichtaufnahme der Gegenwart in der Theologie hat politische Konsequenzen. Die Predigt bestätigt nur das Vorhandene, sie konserviert, statt zu emeuern".

Wat Bohren sê, was waar in Duitsland tydens die tydperk van die Nazisme, in Nederlandse na-oorlogse sekularisme en in Suid-Afrika nadat politici die moreel-regverdigbare Tomlinsonplan opgeskeur het. Die kerke het die plan in 'n volkskongres in 1956 toegejuig, maar daarna ewe gedwee agter Verwoerd aan ou kolonialisme onder die noemer apartheid begelei, omdat regering en lidmate dit van hulle verwag het. Die Sinode van die GKSA van 1994 het weer 'n nuwe 'demokratiese' bestel kritiekloos gesanksioneer, sonder om na die teokrasie of eie sinodale Skrifstudies en getuienis van 1958 tot 1976 oor die Suid-Afrikaanse situasie te kyk. Normlose bediening dien nie die koninkryk nie.

Wanneer die 'kerk' die (ekklesiologiese) vertrekpunt vir diakoniologie sou vorm, bepaal dit as samelewingsverband op horisontale vlak naas staat en samelewing sy eie norme, ampte, werkswyse en oogmerke. Wanneer die koninkryk van God (Christologie) egter die vertrekpunt vorm, moet die diakoniologie die norm vir die bedieninge en diens vir, in en uit die empiriese kerk aan die Skrif en universele kerk ontleen. Die koninkryk as vertrekpunt sluit nou aan by wat Firet (1968b:9) God se koms na mens en wêreld en God se naby-wees in sy Woord (Firet, 1968a:25 e.v.) noem. 


\section{Enkele basiese rigtingwysers vir diakoniologie}

\subsection{Diakoniologie is basies op die enkeling gerig.}

Die gevaar bestaan dat die 'gemeente' as 'alternatiewe gemeenskap' en gemeentebou in ' $n$ tyd van sosialisering (vgl. Krikke, 1976:56) en demokratisering (vgl. Hendriks, 1992:14, 21), die aandag van die individu se verbonds- en gehoorsaamheidsrelasie teenoor die Here kan aftrek en aan die enkeling slegs betekenis toeskryf in soverre hy in die groep of gemeenskap funksioneer. 'n Teks soos Efesiërs 4:11-16 (vgl. 1 Kor. 12: 12-28) toon egter aan dat die bediening van die individu die weg is waarlangs die universele kerk groei. Die bedieninge moet egter vir die enkeling in sy lewe betekenis hê (Pannenberg, 1976:433; vgl. Jonker, 1968:5 e.v.). Dingemans (1991) sê tereg (hoewel eensydig) dat die hoorder die prediking moet bepaal. Die besondere dienste (Spoelstra, 1989:28 e.v.) en Christelike onderlinge gemeenskap moet die individuele Christen ondersteun sodat hy sy Here 24 uur van elke dag in 'n wêreld vol probleme met blydskap kan dien.

\subsection{Diakoniologie neem die besondere dienste as vertrekpunt}

Pastoraltheologie het sedert die 4de eeu begin besin oor die "Person des Pastors und auf Einzelpersonenen der ihn Anbefohlenen bezogen ist" (Haendler, 1957:5). Daaruit het 'n patroon ontwikkel waarin die gelowiges uit wie en ten behoewe van wie God die dienste in die Nuwe Testament gegee het, tot leke-voorwerpe vir bediening gedegradeer is. Gereformeerde diakoniologie het by die swaar aksent op amp teenoor lidmaat aangesluit (Spoelstra, 1993:83 e.v, Trimp, 1982 a \& b, Hendriks, 1972 ens.) en as 't ware in ampsleer gestol (vgl. Kuyper, 1909b:468 e.v.; Jonker, 1968:18; Booysen, 1980).

Die waarheid dat ook 'ampsdraers' primêr, deurlopend, voluit maar net dienende Christene moet wees (1 Tim. 3; Matt. 28:19; Rom. 10:14 e.v., 16:1 e.v.; Spoelstra, 1989:26-31, 66-70), is deur 'n hiërargiese skeiding tussen ampsdraers en 'lidmate' verkrag. Die koninkryksdoel wat Christus vir die dienste stel, is nie genoeg gemonitor nie. Feedback in bedieningspatrone is feitlik onbekend.

Die foute van die verlede regverdig nie 'n verplasing van die Bybelse herder-kudde-model met 'n liggaam-model (Richards \& Hoeldtke, 1980: "church without walls") om die gemeente daarmee sogenaamd te "ontvries" nie (Hendriks, 1992:39 e.v., 51 e.v., 66-71, 113). Wie die Skrif as 
norm neem, moet God se orde vir sy kerk aanvaar (Spoelstra, 1989:16, 2634). In die Skrif is alle metafore vanuit 'n bepaalde gesigspunt gelyktydig waar. Daarom is dit ongeregverdig om een model teen ' $n$ ander af te speel. Miskien kan 'n mens sê dat God sy handelinge met, deur en in mense op 'n wyse laat geskied wat die herder-kudde-model weergee om die liggaammodel in die universele kerk, die liggaam van Christus, te bereik. Dan kom ons van diakonia aan mense tot die diakonia van mense aan God en aan mense.

\subsection{Diakoniologie is kerkgerig maar nie kerkbepaald nie.}

Wanneer ons sê dat diakoniologie nie soos praktiese teologie sy vertrekpunt in kerklike handelinge neem nie, hang dit saam met kerkbegrip. Wie kerk of gemeente net as sigbare organisasie verstaan, het 'n ander perspektief as die diakonioloog wat primêr handel met die liggaam van Christus, die universele kerk onder een Hoof. (Insake die kerk of gemeente as sigbare organisasie en die kontras tussen 'kerk' en 'gemeente' - kyk Schwarz en Schwarz, 1985.) Die kerk word in die gemeente op 'n bepaalde plek in die eenheid van geloof sigbaar (Heid. Kat 21, NGB 27, 28; Snyman, 1966, 1977:35, 44). Die Christologiese grondslag (Matt. 16:18, 28:19, 20, 1 Pet. 2:5 ens.) verplig diakoniologie om te vra in hoeverre die sigbare, plaaslike kerk die wese, groei en geloof van die universele kerk vertoon (vgl. Spoelstra, 1994).

\subsection{Diakoniologie is op die kosmos gerig}

Bohren wil dat God deur bediening mooi moet word in die skepping (1975: 94 e.v). Hy beskuldig ons geslag dat ons op Neo-Platoniese wyse God nie meer in die sigbare skepping ken nie (Bohren, 1975:136).

Blindheit gegenwärtiger Frommigkeit und Theologie, fü die Schöpfung zum Bleispiel, geht auf augustinisches Erbe zurück, indem es die Schönheit sichtbarer Schöpung neuplatonisch in Gegensatz setz zur Schönheit, die unsichtbar bleibt ... Die Absenz der Schöpfung weithin in der gegenwärtigen Predigt ist zweifellos ein augustinisches, neuplatoniches Erbe: Wer immer nur vom Sichtbaren zum Unsichtbaren fortschreitet, braucht schlussendlich das Sichtbare nicht mehr.

Hy noem Psalm 19 as voorbeeld hoe die "Unsichtbare erscheint im Sichtbaren, wird wahrnehmbar; die Schöpfung wirkt narrativ ..." (Bohren, 1975:138 e.v.).

Met die koninkryk van God as vertrekpunt kan diakoniologie nie langer Neo-Platonies opgaan in diens binne 'n eng kerklik-godsdienstige, geeste- 
like kompartement nie. Daar wag 'n groot taak vir diakoniologie om in die moderne wêreld met sy oorbevolking, vernietiging van hulpbronne, milieuvervuiling ensovoorts, leefbaarheid as voorwaarde vir diens in Gods koninkryk te proklameer (Nijkamp \& Douma, 1974:127).

\section{Enkele konkluderende opmerkings}

Die kernverskil tussen diakoniologie en praktiese teologie berus op die basiese vraag of die dinamiese koninkryk van God of die kerk as empiriese verskynsel as vertrekpunt geneem word.

Tans begin die rasionalistiese Aufklärungs-teologie wat selfs Kuyper nog by 'amp' en 'kerk' laat vassteek het, verbrokkel. Daar kom groter begrip vir die plek van apriorieë in teologie. Gereformeerde diakoniologie kan sy ondersoek rig vanuit die vertrekpunt van die koninkryk (koningskap) van God. Sodoende kan die handelinge van die Drie-enige God wat in die wêreld, sy volk en individu neerslaan, ondersoek word en op deugdelike wetenskapsteoretiese gronde 'n teologie uitgebou word wat aan horisontalisering en relativering ontkom.

Diakoniologie moet binne die geheel van teologie met verantwoorde metodes so veel as moontlik geverifieerde en gesistimatiseerde kennis (Stoker, 1969:134-138, 241 e.v.) omtrent die bediening en vergestalting van die koninkryk van God in die wêreld en onder mense uitbou (Spoelstra, 1993: 74-76). Daarvoor moet diakoniologie homself rekenskap gee van sy bepaalde geloofsapriorieë of voorveronderstellings (vgl. Stoker, 1969:33, 140 e.v., 244) asook van dié van ander 'teologieë' waarmee hy in gesprek tree. Aleopatie en homeopatie verskil in die mediese wetenskap omdat hulle voorveronderstellings verskil.

Van Wyk (1991:76-84) het beswaar teen 'n konfessionele benadering, maar bied self nie ' $n$ alternatief nie. Hy gebruik begrippe wat op voorveronderstellings berus, soos byvoorbeeld "praktiese teologie as handelswetenskap" of "gemengde tipe" teologie. Konfessionele teologie plaas sy teologiese voorveronderstellings met 'n konfessie op die tafel. Die Skrif is geïnterpreteer en saamgevat in die Formuliere van eenheid (belydenis) wat gemeenskaplike geloof verwoord (Spoelstra, 1989:297-298). Die kom van God se heerskappy in en deur die diens van mense moet binne die konfessionele konsensus van daardie gemeenskap werk, anders breek teologie die eenheid en daarmee per definisie die kerk af. 
Hoewel my voorveronderstellings van Van Wyk (1991:76 e.v.) verskil, stem ek saam dat Jonker (1968:24) verkeerdelik die bron vir teologie en diakoniologie tot die Skrif beperk. Vakke soos kerkgeskiedenis en diakoniologie het nie soos bibliologiese vakke net die Skrif as bron nie (vgl. Spoelstra, 1993:85 e.v.). Die bronne om die koms van God se heerskappy (koninkryk) in die wêreld te ken is wyer as die Skrif, maar die kennis moet kragtens teologiese metode met die Skrif as norm nuut geïnterpreteer word. Soms dien die Skrif as bron en dan weer as norm wanneer kennis uit ander bronne geneem word.

'n Mens kan jou met die Skrif as norm verantwoord om aan diakoniologie as besondere studieveld die teokrasie of ingrype van God in die wêreld, die handelende heerskappy van God, die bediening en vergestalting van die koms van sy koninkryk, teenwoordig en toekomstig (Ridderbos, 1950:5, $16,19,25,30,35-68,102$ e.v.) aan te wys. Dit gaan om "Gods macht en regiment" maar ook om die "effectuering daarvan", naamlik "van de realisering van zijn rijk, van zijn komen tot de wereld om Zich in zijn koninklijken majesteit ... te openbaren" (Ridderbos, 1950:36).

God gebruik ook in sy kom na die wêreld dienaars wat vir Hom onder andere deur die bediening van die Woord en Gees 'plaasvervangende werk' doen (Calvyn, 1992:1276, 1318; Spoelstra, 1989:18, 26-34; Rom. 10:15; Ef. 4:11-16). Diakoniologie moet dus die handeling van die eintlike Subjek - God - die handeling wat Hy deur geroepe dienaars en instrumente in die groei en opbou van sy kerk verrig en die diens van die mens(e) in wie Hy werk, die gelowiges, ondersoek. Laasgenoemde aspek is in Roomse en gereformeerde teologie dikwels verwaarloos, terwyl Heitink (1990:206, 208) juis 'ervaringsteologie' hoog aanslaan.

Diakoniologie kan met empiriese metodes ook 'n feedback oor die grondvat van die handelinge van God in die gelowige(s) daarstel - maar moet waak dat dit nie die mistiek van God se werk in mense aantas nie. Die besondere dienste ('ampte') moet egter minder as 'beskutte arbeid' benader word asof die gemeente terwille van die dienste daar is. Die vraag hoe doelmatig en selfs effektief ' $n$ bepaalde dienaar in konkrete situasies funksioneer, kan ondersoek word, omdat 'n bepaalde 'dienaar' kommunikasie tussen God en mens kan strem.

\section{Bibliografie}

BOHREN, R. 1975. Dass Gott schön werde. Praktische Theologie als theologische Ästhetik. München : Kaiser. 
BOOYSEN, D.J. 1980. Praktiese Teologie vanuit die Hervormde Teologiese Opleiding aan die Universiteit van die Noorde. Pietersburg : Univ. van die Noorde.

CALVYN, J. 1992. Institusie van die Christelike Godsdiens 1559. Vertaal deur H.W. Simpson. Potchefstroom : CJBF.

DE WET, C.J.H. 1921. Die kollegiale kerkreg. Amsterdam : Vrije Universiteit. (Ph.D.-proefskrif.)

DIJK, K. 1952. De dienst der kerk. Kampen : Kok.

DINGEMANS, G.D.J. 1987. Een huis om in te wonen. Den Haag : Boekencentrum.

DINGEMANS, J.D.G. 1991. Als hoorder onder de hoorders. Kampen : Kok.

DREYER, T.F.J. 1991. Eerste treë in die Praktiese Teologie: Waarheen? Hervormde Teologiese Studies, 47(3):597-608.

DU PLOOY, A. le R. 1982. Kerkverband - 'n Gereformeerd-kerkregtelike studie. Potchefstroom : PU vir CHO. (Th.D-proefskrif.)

FIRET, J. 1968a. Het agogisch moment in het pastoraal optreden. Kampen : Kok.

FIRET, J. 1968b. Praktische Theologie als theologische Futurologie. Kampen : Kok.

FISCHER-BARNICOL, H. 1969. Theologische Methode und Mystische Erfahrung. (In Neuenzeit, P. red. Das funktion des Theologie in Kirche und Gesellschaft. München : Kösel. p. 88-109.)

HAENDLER, O. 1957. Grundriss der Praktische Theologie. Berlin : Alfred Tröpelmann.

HEITINK, G. 1990. Theologie en Psychologie: een spanningsveld. Gereformeerd Theologisch Tijdschrift, 90(4):206-220.

HENDRIKS, J. 1990. Een vitale en aantreklijke gemeente. Kampen : Kok.

HENDRIKS, J. 1992. red. Gemeentes vertel. Verandering in 'n Christelike geloofsgemeenskap. Gemeente en bediening Nr. 2. Kaapstad : Lux Verbi.

HEYNS, L.M. \& PIETERSE, H.J.C. 1990. Eerste treë in die Praktiese Teologie. Pretoria : Gnosis.

HORNIG, von G. 1991. Wahrheit und Historisierung in Semmlers kritische Theologie. Theologischer Literaturzeitung, 116(10):722-730.

JENSSEN HANS-HINRICH e.a. red. 1975. Handbuch der Praktischen Theologie. Band I: Die Praktische Theologie (Einfurhung) Gestalt, Aufbau und Ordnung der Kirche zur Person des kirchlichen Amtsträgers. Berlin : Evangelische Verlagsanstalt.

JOHANSON, B.O. 1973. Praktiese Teologie. (In Eybers, I.H.; König, A. \& Stoop, J.A. red. Inleiding in die Teologie. Pretoria : NG Kerkboekhandel p. 169-180.)

JONKER, W. 1968. Theologie en praktijk. Een peiling van het theologisch karakter van de diaconiologische vakken. Kampen : Kok. 
JOUBER, W.D. 1977. What is Theology? (In Church and Theology in the Contemporary World. Grand Rapids : RES Secretariat. p. 4-15.)

KLOOSTER, F.H. 1977. Theology, Compassion and the Church. (In Church and Theology in the Contemporary World. Grand Rapids : RES Secretariat. p. 21-38.)

KÖNIG, A. 1973. Die teologiese wetenskap. (In Eybers, I.H.; König, A. \& Stoop, J.A. red. Inleiding in die Teologie. Pretoria : NG Kerkboekhandel.)

KRIKKE, S. 1976. Veranderd levensbesef en liturgie. Assen : Van Gorcum.

KUYPER, A. 1883. Tractaat van de reformatie der Kerken. Amsterdam : Höveker \& Seun.

KUYPER, A. 1908. Encyclopaedie der Heilige Godgeleerdheid. Deel 1. Kampen : Kok.

KUYPER, A. 1909a. Encyclopaedie der Heilige Godgeleerdheid. Deel 2. Kampen : Kok.

KUYPER, A. 1909b. Encyclopaedie der Heilige Godgeleerdheid. Deel 3. Kampen : Kok.

LOUW, D.J. 1992. Die ontwerp van 'n prakties-teologiese ekklesiologie vir gemeentebou. Praktiese Teologie in Suid-Afrika, 7(2):119-136.

LOUW, D.J. 1993. Praktiese Teologie - 'n Fenomenologiese stuiptrekking? Praktiese Teologie in Suid-Afrika, 8(2):206-209.

NEL, M. 1987. Die verhouding van gemeentebou tot ander dissiplines van die vak Praktiese Teologie en ander teologiese vakke. Praktiese Teologie in Suid-Afrika, 2:26-37.

NIJKAMP, P. \& DOUMA, J. 1974. Het gelaat van de aarde. Enige beschouwingen over milieuproblematiek. Groningen : De Vuurbaak.

PANNENBERG, W. 1976. Theology and the Philosophy of Science. London : Darton, Longman \& Todd.

PIETERSE, H.J.C. 1991a. Die wetenskapsteoretiese grondslag van die Praktiese Teologie. Praktiese Teologie in Suid-Afrika, 6(1):38-51.

PIETERSE, H.J.C. 1991b. Praktiese Teologie as praktiese wetenskap binne die teologiese fakulteit. Praktiese Teologie in Suid-Afrika, 6(2):249-254.

PIETERSE, H.J.C. 1994. Metateorie as wetenskapsbenadering in die Praktiese Teologie. Praktiese Teologie in Suid-Afrika, 9(1):93-100.

RICHARDS L. \& HOELDTKE C. 1980. A Theology of Church Leadership. Michigan : Zondervan.

RIDDERBOS, H. 1950. De komst van het koninkrijk. Kampen : Kok.

SCHLEIERMACHER, F.D.S. 1830. Kurz Darstellung des theologischen Studiums zum Behuf einleitender Vorlesungen. Berlyn : Otto Hendel.

SCHLEIERMACHER, F.D.S. 1968. Schleiermacher-Auswahl. Mit einem Nachwort von Karl Barth. Bollie, H. red. München \& Hamburg : Siebenstern.

SCHWARTZ, F. \& SCHWARTZ, G.A. 1985. Theologie des Gemeindeaufbaus: ein Versuch. Neukirchen-Vluyn : Aussaat. 
SMALBRUGGE, M.A. 1991. De ondergang van de systematische theologie. Kerk en Theologie, 42(1):28-41.

SNYMAN, W.J. 1966. Universele en plaaslike kerk. Die Kerkblad: 8, Jul. 13.

SNYMAN, W.J. 1977. Nuwe en ou dinge. Uit die skat van die koninkryk. Potchefstroom : Pro Rege.

SPOELSTRA, B. 1981. Calvyn se kerkreg en invloed op die kerke in SuidAfrika. In die Skriflig, 15(59):4-23.

SPOELSTRA, B. 1989. Gereformeerde Kerkreg en Kerkregering. 'n Handboek by die Kerkorde. Hammanskraal : Teologiese Skool.

SPOELSTRA, B. 1991. Kerkreg en diakoniologie (praktiese teologie) in die teologiese ensiklopedie. Praktiese Teologie in Suid-Afrika, 6(2):206-226.

SPOELSTRA, B. 1992a: Dilemma tussen praktiese teologie en ekklesiologie. Theologia Reformata, 35:(4) 299-306.

SPOELSTRA, B. 1992b. Op soek na 'n paradigma vir kerklike gesag met kerkreg en praktiese teologie as parameters. Hervormde Teologiese Studies, 48(2 \& 3): 1-22.

SPOELSTRA, B. 1993. Besinning oor die teologiese ensiklopedie van Kuyper met kerkreg en diakoniologie as parameters. In die Skriflig, 27(1):69-89.

SPOELSTRA, B. 1994. Liturgiese handelinge stel nie vanself 'n erediens as ontmoeting met God (godsdiens) daar nie. In die Skriflig, 28(1):37-56.

STOKER, H.G. 1969. Beginsels en metodes in die wetenskap. Johannesburg : De Jong.

TE VELDE, M. 1989. Gereformeerde gemeenteopbouw. Een eerste koersbepaling voor een nieuw theologisch vak. Kamper Bijdrage, 30:5-44.

TRIMP, C. 1982a. Zorgen voor de gemeente. Kampen : Copiëerinrichting van den Berg.

TRIMP, C. 1982b. Ministerium. Een introductie in de reformatorische leer van het ambt. Groningen: De Vuurbaak.

VAN RULER, A.A. 1952. Bijzonder en algemeen ambt. Nijkerk : Callenbach.

VAN WYK, A.G. 1991. 'n Verkennende gesprek rondom die begrip teologie in verskillende praktiese teologiese benaderings. Praktiese Teologie, 6(1): 76-85.

VENTER, C.J.H. 1992. Diakoniologie en rasionaliteit - 'n Verkenning. In die Skriflig, 26(1):29-51. 